\title{
Neural Tube Defect
}

National Cancer Institute

\section{Source}

National Cancer Institute. Neural Tube Defect. NCI Thesaurus. Code C84923.

A cong enital defect characterized by failure of the neural tube to close completely; this results in the presence of openings in the brain or spinal cord. Examples of neural tube defects include encephalocele and spina bifida. 